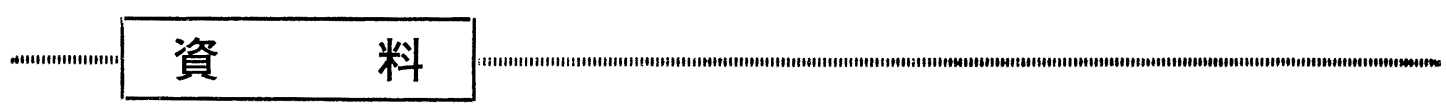

\title{
東海道新 幹線とゴム
}

\section{田 中 瑞 穂*}

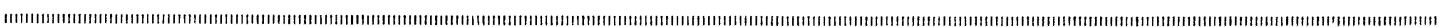

\section{1. は じめに}

文化の発展とともに高分子材料はいよいよわれわれの 人体の組織の中にまでも浸透してきている昨今である が，高分子材料の中でゴムがプラスチックと異なる点 は，その緦大なる弹性にあり，この特性を利用してこそ ゴムのうま味があるわけである。

鉄道においても，まだ新幹線が話題になる以前から， 将来いかに最も近代的な鉄道をつくるべきであるか，ま たそのためにゴムをいかに利用すべきかが論議されてい た、その一つにモノレール論があったが，あらゆる知恵 を絞っての論議であったということは想像にかたくな い.しかし当時はゴムタイヤとコンクリートの路線では 摩擦, 分岐器, 追い越し, 折り返しなどの点で幾多の問 題があり, 果して長距離列車として輸送能力の増大の可 能性があるかどうか疑問であった。, 一方東海道線は, や がては行詰ることが予想され，巷には鉄道の斜陽化諭も チラホラ聞え, その将来に悲観的な人も多かった。

しかし何としても東海道輸送力の増強は国鉄にとって は必至の急務であった.丁度その折, 鉄道技術研究所の 創立50周年を記念して, 去る昭和32年 5 月銀座山葉ホー ルで公開講演会が催され, その席上で超特急列車, 東京 一大阪間 3 時間への可能性の報告がなされ, 車両は軽構 造, 低重心, 筀気ばねの電車とし, 振動は現在の数分の 一程度となり，乘心地は快適なものであろうとの内容で あった。これがきっかけとなり, 当時の国鉄総裁十河信 二氏は, この大事業の進軍を命じたのである。

それより 7 年の歳月を経た昨年の 10 月には, ついに夢 の超特急「ひかり号」として世界にデビューした. しか して超特急「ひかり号」は「こだ亡号」から発展し, 今 日に至ったのであって，この計画が本決定してより完成 まで 5 ケ年ということであり, 研究, 工事などのことを 考えると, 非常な大事業であり, まして研究においては

$*$ 鉄道技術研究所
国鉄内外を問わず，土木，電気，車雨，運転，施設，材 料その他各部門の総力を挙げての態勢であった。中でも ゴム製品は䔖の製品として，実に多種多様の製品が，各 分野にわたって使用されているのであって，ここでこの 全貌を紹介するには紙面が許されない．またその $1 つ 1$ つのゴム製品には幾多研究の努力が秘められているので あって，一日にして成ったのではなく，各方面の絶大な る協力を得た結果として生まれたものであることをわれ われは忘れることはできない。

しかして，列車が高速になればなるほど，車両にとっ てはゴムはなくてはならないものであることを痛感し， 将来ますます開拓されていくべき高分子材料の1つであ ろうと信ずる。それでは次に新幹線に用いられているゴ ム製品の主なものを拾ってみることにする。

\section{2. 新幹線に使用された主なる ゴム製品の実用例}

\section{1 乾道用タイパッド}

すでにいろいろと紹介されているので，ご承知の方む 多いと思うが，軌道用タイパッドというのはレールとま くらぎの閂に挿入する緩衝用材料である。軌道權造とし ては軌道の狂いが小さく, 保守が経済的で, かつ容易に 交換が行われるものが望まれるわけであるが，そのよう な䍹造の設計としては，レールを大きくすること，レー ルとまくらぎとの間に挾を軌道用パッドを軟かくするこ と，边くらぎを重くすることなどいろいろの方法があ る.これらの構造を作るには, レールとまくらぎ, 䋨結 装㯰, 道床などの設計をしっかり行ない, それらの組合 せによって，ガッチリした軌道棰造とするものである。

新幹線のレールは, $1 \mathrm{~m}$ 当り $53.5 \mathrm{~kg}$ 重さで, 在来線 より $3.3 \mathrm{~kg}$ も重く, レールの底面の幅も $136 \mathrm{~mm}$ 之在来 線より $9 \mathrm{~mm}$ も広くなっている。またまくらぎは橋と分 岐器の部分をのぞいて,丈夫で耐久性の P.C.(Prestressed Concrete) まくら木を使用している.

軌道構造は当初アスファルト道床, あるいは砕石を用 
いないなど無道床構造が検討されたが，道床破猿の実騙 計算により，大部分が有道構造となり，したがって新幹 線の一般的軌道構造は䂗石道床，P.C.\&くらぎ，二重弾 性締結，ロングレールを用いている，軌道用パッドも第 1 種と第 2 種とあり，第 1 種は主としてレールの木まく らぎへの喰込み防止用であるが，管 2 種よりかたく，耐

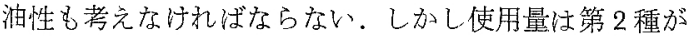
多いので，第 1 種の方渻略させていただくが，第 2 種 パッドは主としてコンクリートまくらぎ用で軟かく，厚 さは在来線のものより $1 \mathrm{~mm}$ 厚く $7 \mathrm{~mm}$ となっている。 また大きさも大きく, 耐久性も種々研究の条，瘦労に関 する項目などを加味して，乙の耐久性に期待を加けてい 万。

ここで話は少し外机るが，レールの締結装置も表 1 亿 示すように，使用目的により区別されている。幹線に用 いられている締結装置の1例を図1，図2に示してある が，一番多く使用されている102型は図 3 に示すよら に，二重弾性締結装置で一つのレール締結装置に働く䌙

装 1 新幹線に使われているレール締結装置の種類と 使用分類例

\begin{tabular}{|c|c|}
\hline 繰結装置の種類 & 使 用 筒 所 \\
\hline $102,103,105$ 型 & コンクリートまくらぎ用 \\
\hline 204，205型 & 木まくらぎ用 \\
\hline 304型 & ホブロック直結用 \\
\hline 404 a 型 & 橋上直結用（レール国定） \\
\hline $404 \mathrm{~b}$ 型 & 橋上直結用（レール可動） \\
\hline
\end{tabular}

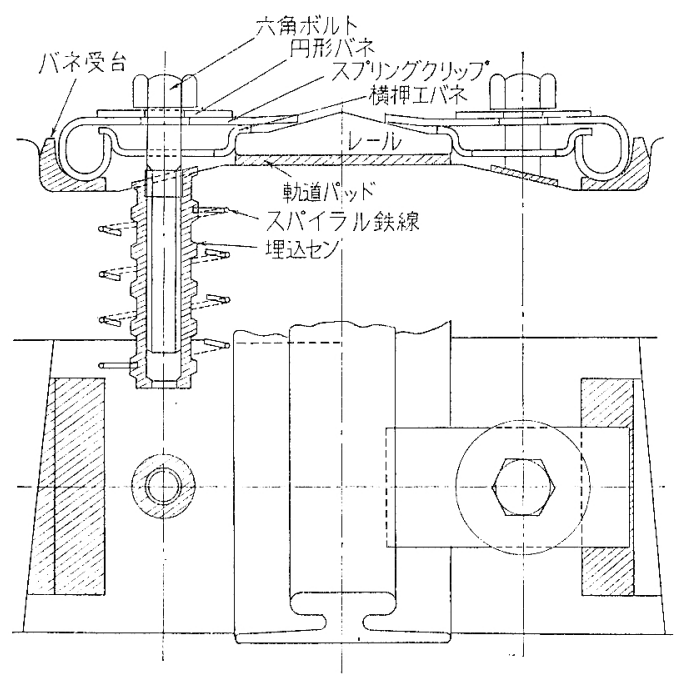

図1 102 型レール蟐結装置の例 (コンクリートまくらぎ用)
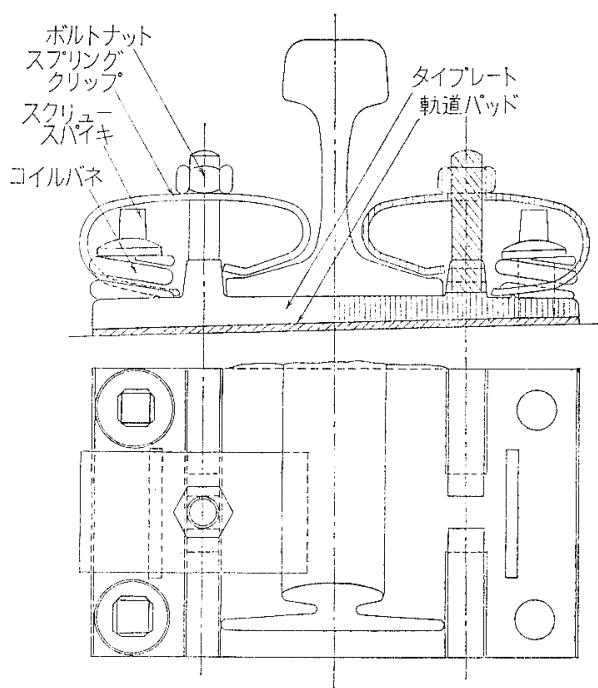

図 $2404 \mathrm{a}$ 型レール締結装置の例 (橋上まくらぎ用)

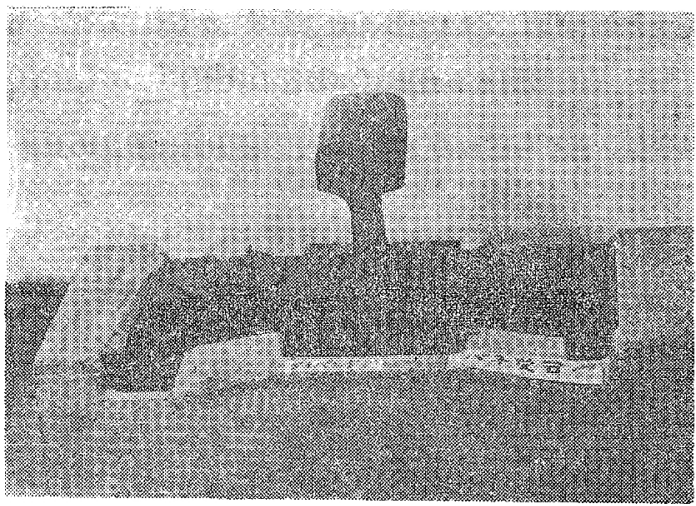

因 3 レール締結状態

圧を減少させて，コンクリートの横圧止め部の保護をは かるため，横押えげるをスプリングクリップ後端曲上げ 部とレール底縁との間に骦入しこれるるタサビ状のプ

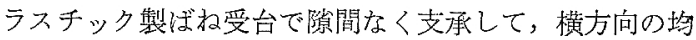
等弾性支承をはかってある。このクサビ状惊ね受台は製 作比なら製作公差によるガタを解決し，轨間の微少 な直しはこれを利用する。しかして勒道パッドのばね常 数住 $90 \mathrm{t} / \mathrm{m}$ で在来 $(100 \mathrm{t} / \mathrm{m})$ 占り軟かく，高速運転にお ける振動衝整を吸収し，これにともないスプリングクリ ップのレール押え位置のばね常数を下げて，ばねの応力 变動を少くするとともに，初期紹結力によるたわみ量を 充分大きくして軌道パッドの永久ひずみやばね受台の喰 込みによる締結力の肔緩を防止している。しかしてその

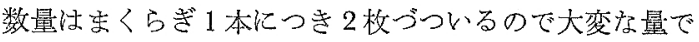


ある.また使用状態が衝撃のくり返しのようなもので, し かも夏季はレールの温度が $50^{\circ} \mathrm{C}$ 近くまで上昇するので, 条件としては非常にか酷で，耐久性のある製品を作るこ とはなかなかむづかしいが，材質は現在のところ NR， CR，SBRなどが用いられている。

\section{2 空気ばね}

車両においても振動防止の研究が進められ，現在では 従来の台車の振動の $1 / 4$ 以下となっている．車両の振動は いろいろのところからくるので複雑であるが，空気ば数 についてみると，このば祍系は図4 亿示すような変遷を たどっており，昔は図4(a)に示すように，上下方向には

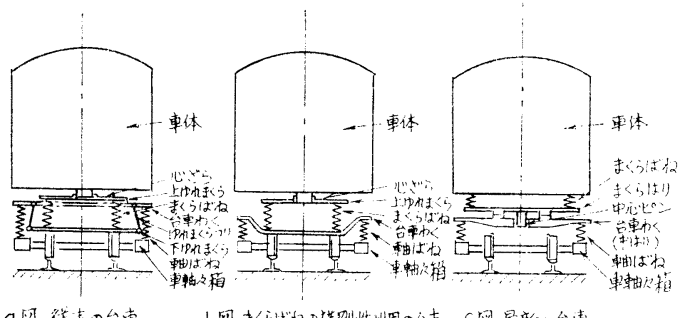
a国，徒东の台事

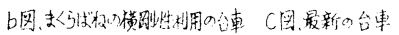

図 4 台車ばね装置の変遷

軸ばね, まくらばねの 2 段装置で, 横方向の緩衝のため に，ゆれまくら機構が使われていたが，昭和26〜 7 年項 よりコイルばね，昭和33年に「こだま」「あさかぜ」に 空気ば政が使われだしたが，ゆれまくら機構はピンの摩 耗などのため保守にやや難があり，空気ば视の横剛性を 使ってゆれまくらを止めたいという考えが起きて，図4 (b)の上うな台車が出現し，この結果まくらばねは上下方 向の振動緩和作用をしながら，同一ば齐が横方向の振動 緩和をするという考えから，この型が使われだし，最近は 北陸特急に使われている，新幹線はこの形の変形で車体 のロールを防ぐため図 4 (c)のように空気ばねの高さを高 くし，車体の下に直接つけるようにしてある，新幹線に このような空気ばね（ダイヤフラム形）が用いられるよ うになったいきさつを述べると「「こだま」「あさかぜ」

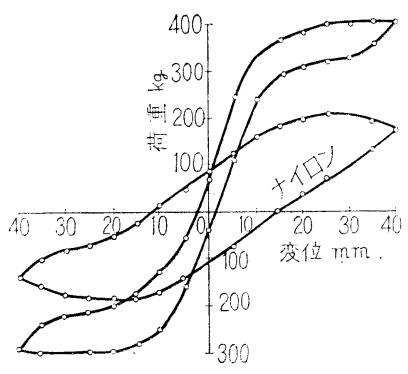

図 5 ベローズ型空気ばねの横方向荷重特性
に使われていた重直用空気ばね（ベローズ型）は横方向 の荷重試験をしてみるとヒステリシスカーブが変った特 性を示し(図 5 ) 欠点として, i) 非線形性があり, ii) 七 ステリシスが大きく， iii) ば放常数が振幅により変り, iv）そのヒステリシスは耐久性の不安を示し，v)さらに 特性が外気湿温度などの影響を受けやすく，不安定で信 頼性が吕しかった。したがって車の横外力を受けたの ち，横外力が去っても車体が元に送らないなどの大きな 欠点があらわれたので，種々改良を加え図 6 に示すよう
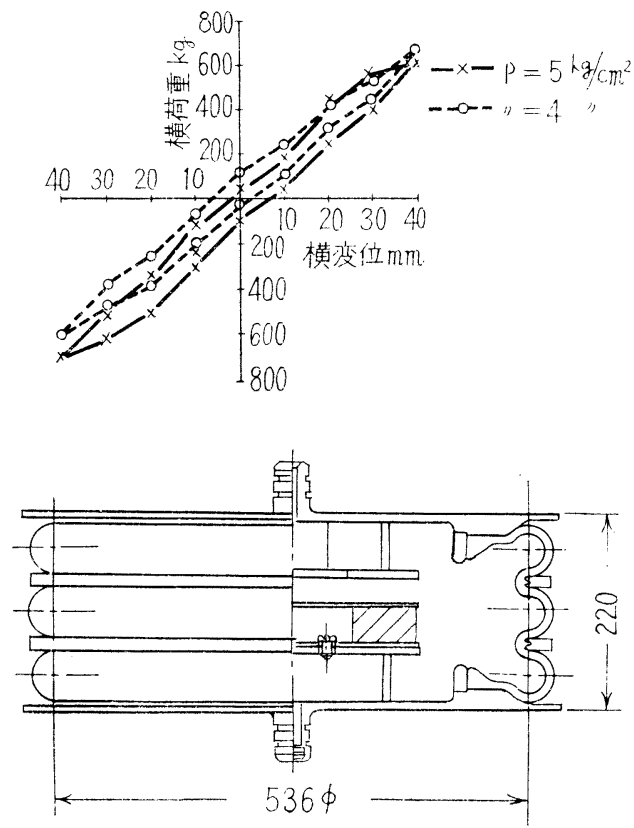

図 6 改良ベローズ型空気ばね

な改良ベローズ型空気ばねが現われヒステリシスカーブ は直線性を示すようになったが，その後ベローズ型をや め，横変位に効する安定性のよいダイヤフラム型(図 7 ) となった，材質は最初のベローズ型の頃はNR系であっ たが，きれつなど耐久性に問題があり，最近は CR 系と なっている。

\section{3 連結器用緩衝ゴム}

車両と車両との連結器（図 $8($ K ) )にも実は緩衝用とし てゴムが使われている。構造は図 8 (口)に示すように鋼板 の両面に，あるいは片面に波状断面ゴムを加硫接着した ゴムパッドを数枚重ねたもので，車凷相互閒の衝撃は一 応この部分を介して車体台わくに少を伝達分散させるの であって，この緩衝容量は $950 \mathrm{~kg}-\mathrm{m}$ となっている。む た連結器の○リングはニトリルゴムが使用してある。 

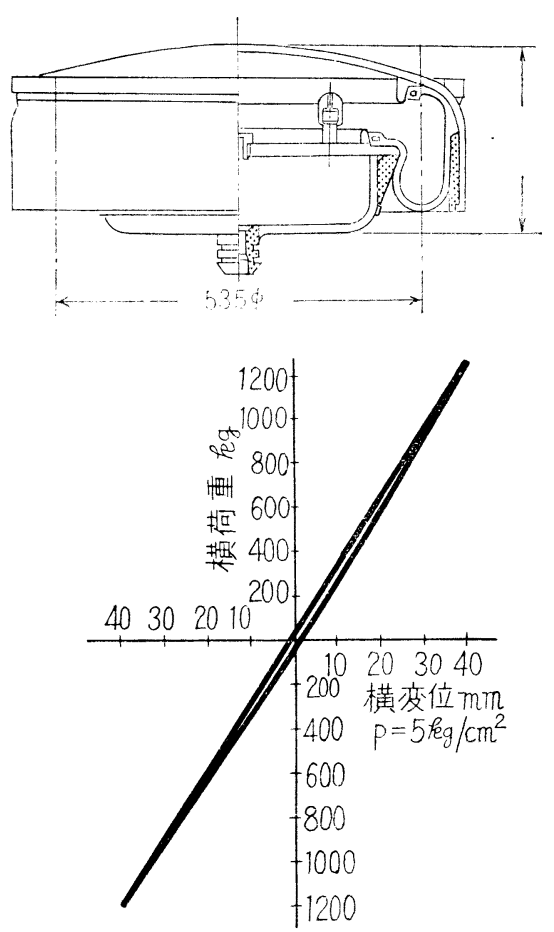

四 7 ダイヤフラム型空気ばね

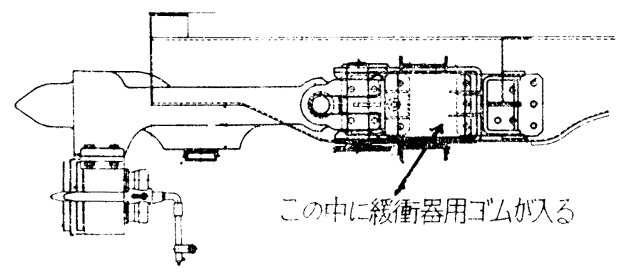

汹 8 (1) 速結器

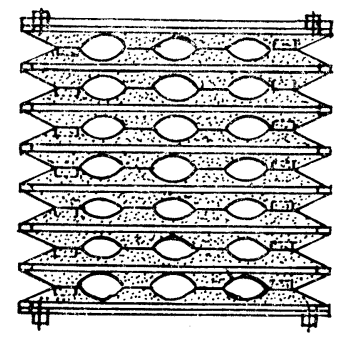

図 8 (ロ) 緩衝器用ゴム

\section{4 防振ゴム}

ゴム製品はパッキングの目的の他に広い意味で防振用 として，何らかの形で用いられているので，とくにあら ためて防振ゴムというのは扮かしいかも知れないが，形
物防振ゴムとしては，種類も多くここに一つ一つ紹介し きれないが，鉄道車両に対して防振ゴムほどゴムの特徽 を充分に生かした使い方をされているものはないといっ てもいいくらいである.

用途としてはｉ）機械類の据付けのように割合に定常 的な振動に刘しての防捺用，ii）衝揧力を緩和する 目的 の緩衝用, たとえば緩衝器用ゴム(前述), ストッパー用 ゴム (図10(人))，ｉii）在来のゴムの特性である高周波振動 を防止し，車同の運動にある程度の自由度をもたせるた

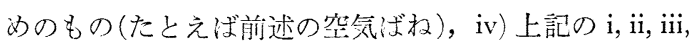
を兼数備えるもの（たと光壮ボルタアンカ用ゴム)な どあるが，中でも脱線の原因ともなる蛇行動（図 9）の

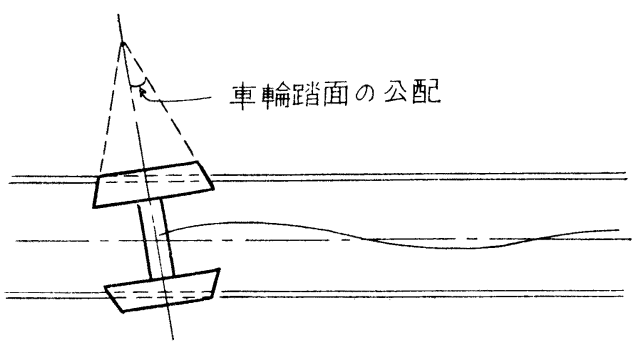

車輪軸の蛇行動

図 9 車輪蟿の蛇行動

ように龺両が左右に摇れる運動が鉄道車両では一番危険 でここに使用されるゴムは実にうまく使ってある，普 通注車雨の走行中の横圧/垂直圧が0.8以下にとってある が，この他「こだま」型でも時速 $180 \mathrm{~km}$ を出すと急に 台車の左右動が生じ振動が激しくなるなど，高速になる ほどいろいろと問題が生じてくるのでやっかいである. ところで蛇行動防止のため車両運動, 女るいは車両構造 研究室で $1 / 5$ モデル実験や本ものの台車試験などで研究の 末, 以前考えられていた考と逆に車両は前後方向ではで きるだけかたく，左右方向ではある程度の軟かさで支持 することが望ましいという教えに変ってきており，これ は車輸の踏面の勾配の問題 (刨配が急になると蛇行動が 大きくなる）もさることながら，ボルスターアンカ用ゴ ム (図 $10($ (1)(口)), 側受用ゴムなどの防振ゴムなどは蛇行 動防止の重要なファクターの基をなすものである。す なわち台車がレール上にて左右に首を振る作用を防止す る。しかし車両の振動は上下, 左右と非常に複雑で解析 はむづかしいので，一つ一つ実験と解析を重ねて現在の 「ひかり」号が生れたのである，材質は主として天然ゴ ムで耐久性付与のためクロロプレンゴムが被稪してある ものが多く，これらは用途用途によりそれぞれのばね常 


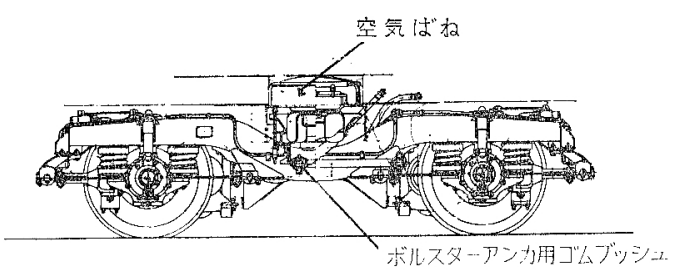

(1)

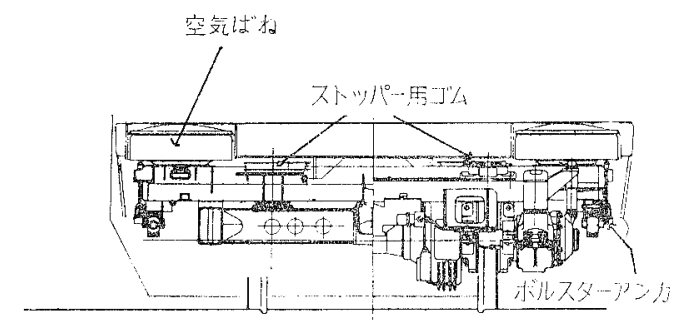

(口)

図10(1)，(口) 台車組立図

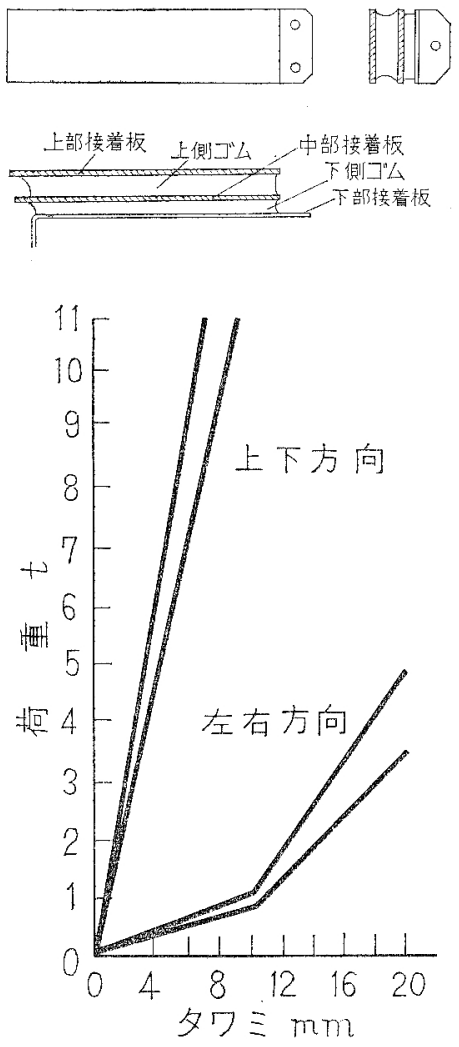

図10(以) ストッパー用ゴム
数が与光られて扣り，形も使用目的により種々雑多であ る.

\section{5 排障器用ゴム}

在来線では踏切が多く，したがって交通事故の大半は この踏切事故で，幹楾で法この踏切を一切なく，道路 との交差方げて立体交差で亦り，飞とえ高速道路での 自動車事故があっても，幹線には被害がない上う離れて いる。しかしてそ礼でもなお，線路上の障害による事故

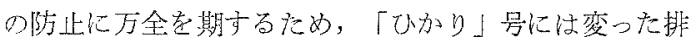

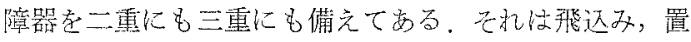
石などの事故やいたずらがあるからで，高速列車に一層 の宾全性が強調さ机るの怯走礼が大きな事故之結びっく 可能性が每るからである。新閏などにこの種の事故，い たずらが報道されているがその対策には，障害物探知機 や，監視貣を置いたり金網孙どを沿線に張るなどの苦心 をしている。先に新聞などを䀼ぎわした事故は，種々研 究した成果の有效性を立証したといら点で不幸中の宰で あったが，心なさ人の俥活ずみな行為は瑗に慎しみたい ものである，所で線路上の障害物の排除のためには，種 々実歌の未，現在は図11に示すよらにモールド成型した 厚さ $22 \mathrm{~mm}$ のキャンバス入りゴム (SBR) 板を 2 枚重社 て取付けてあるが，そのレール面に対卞负角度は約 $65^{\circ}$, レール面との距離約 $20 \mathrm{~mm}$ 前後, そして 2 枚目法 1 枚目

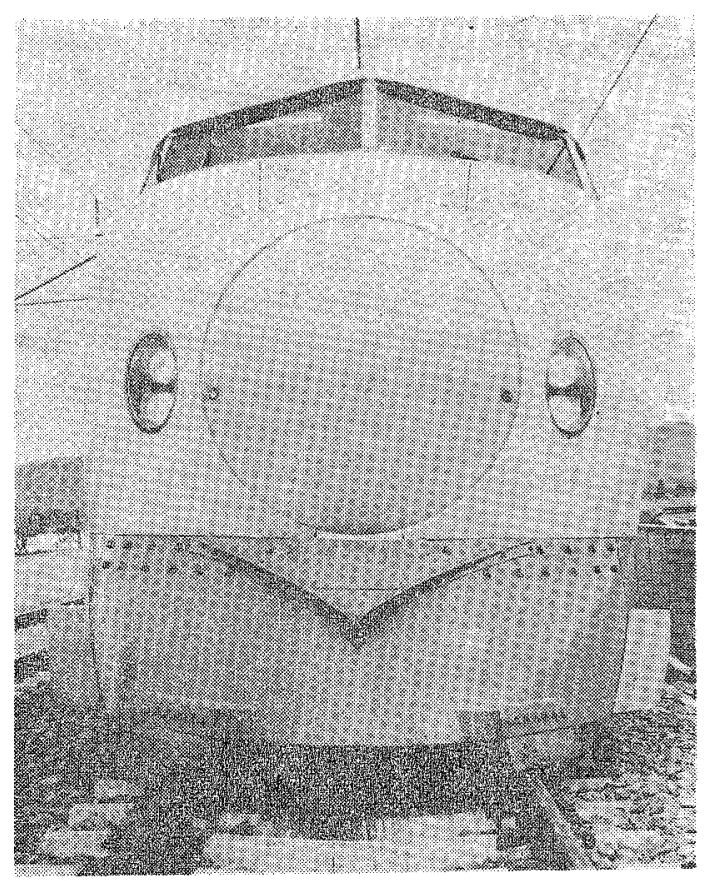

図11 ゴム排障器 
と段違いとなっている。これにより大半の小さな障害物 注排除されるが，少し大きい障害物はスカート内の鋼板 排障器（図12）に上り排除されるわけで嵓る。な抢各車 両にも車輸の近くに排障器の小さなのが付いている。

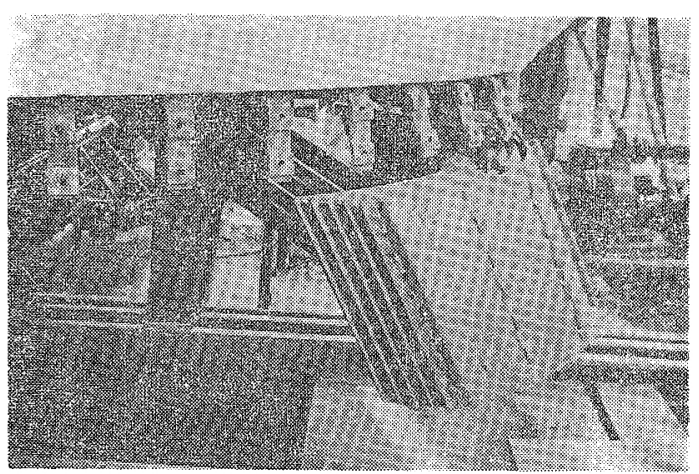

図12 鋼板排障器

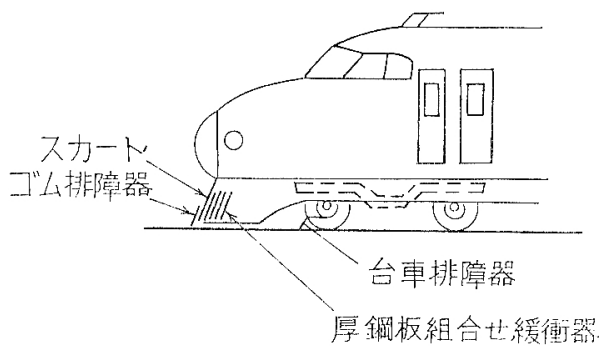

図13 排障器配 列

\section{6 車両断熱材}

床はキーストンプレート上に曆さ約 $10 \mathrm{~mm} の$ 防應合 板导琵り（図14）その閒に硬質ポリウレタンフォーム学

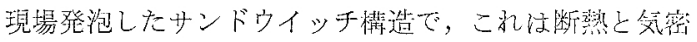
との唒役割を舀している。

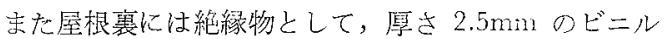
フイルム付ガラス綿保冷板をはり，裹にはポリウレタン フォームが $5 \mathrm{~mm}$ 厚さではっている。

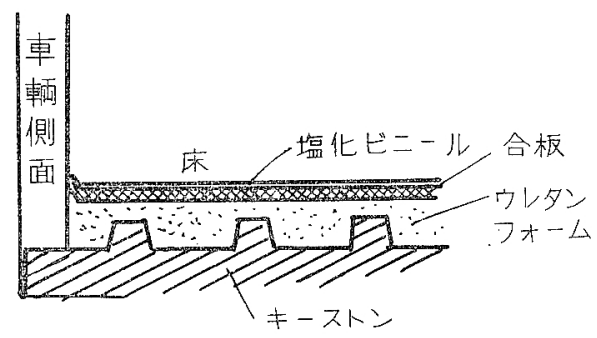

図14 床断熱

\section{7 気密材料}

新幹線のように高速で走る列車は㕵気の流れに対して の考慮をはらわなければならない，このこと法車両棰造 の面で種々研究検討された。し加し車両を実際走らせて みると，トンネル通過時には四に異状な圧力を感じるこ とが分った，急拠これを防止するための対策がとられた のであるが一稒困ったこと海換気装置であり，これをど らするか問題であった。しかし結局は車雨全部学気密代 せざるをえないことがわかったので，現在トンネル通過

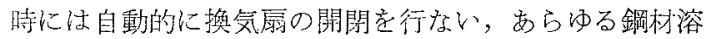
接部，阥閒はゴム系シール材あるいはプラスチックスで 密䦕され，トンネル通過時には，東雨内部洔完全に密害 状態である。

その笑密材料防ゴム系で恬チオコール系ゴム（図15）

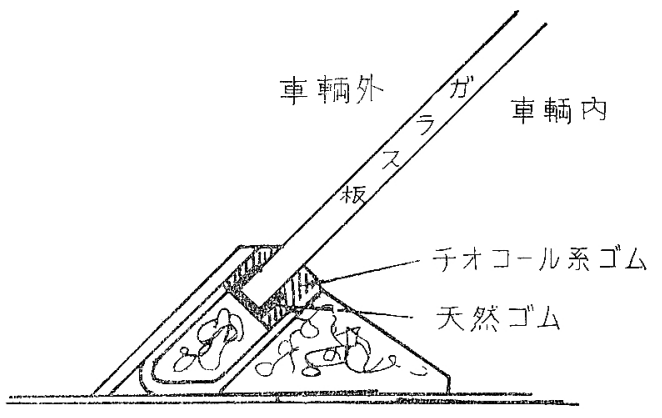

成15 シール材の 1 例

ポリウレタン，クロロプレン，天然ゴムなどが用いられ 変ったところでは, 電線管周国, 電線管内部などはシリ コーンゴムでシールされている。封たリコーンゴムは 標識灯カバーのパッキングにも使用されている。また乗 務貝室密，侧開戸装置には山型をした中空のゴム（膨張 性ゴムシール，図16参照）が用いられ，この中に空気在 入れ膨張して相手側に密着させ，気密を保つようにして ある。东をその他の紐加い点としては，いるいるのネジ

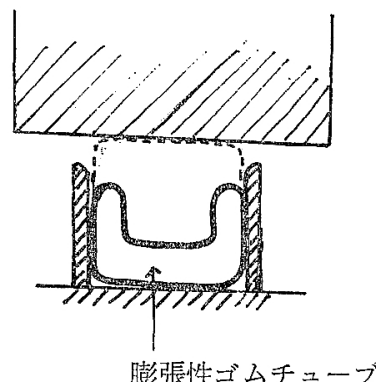

図16 膨張性ゴムシール 
東海道新幹線とゴム

部分や，戸袋内羽板などには塩化ビニルあるいはクロロ プレンコーティングスポンデ型ゴムなどに用いられ，実 に細かいとこるまで気密に心が付ている。

その他ゴム系接着剂もかなり用いられているが，省略 させていただく、ちよっとした亦济のるみや，はずれ などにより新聞にもでていたよらな開かずのドアーでセ ッチン詰になったり，客車内に缶詰になったりするよう な事故が発生する可能性功あるから，気密江すればする ほど工事は情重でなければならない。

2.8 卡口

車両連結部にある内ホ口涀車亚のように通路の近く

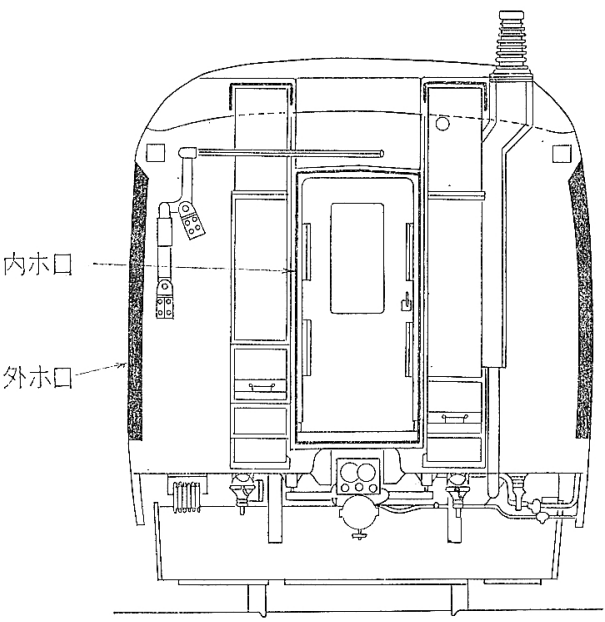

図17(1) 小

口

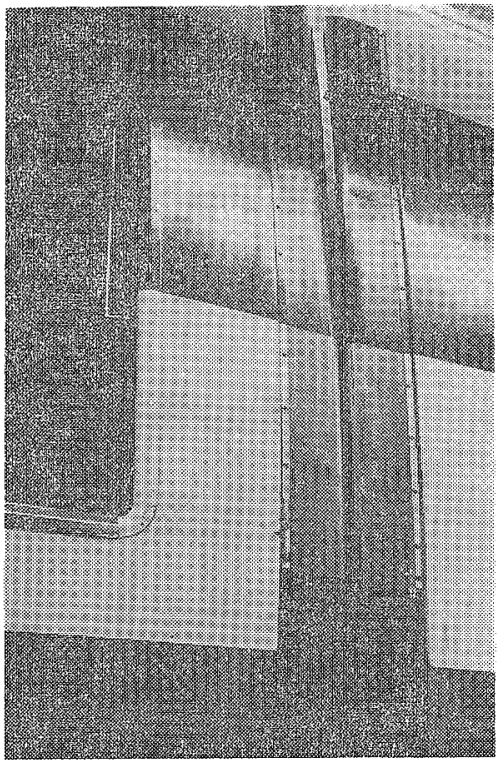

図17(只) 外示口外側

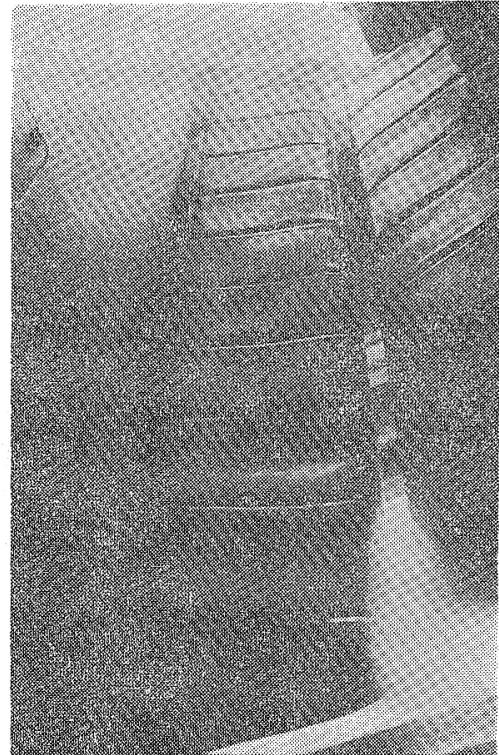

図17(外多口们側 前部車雨
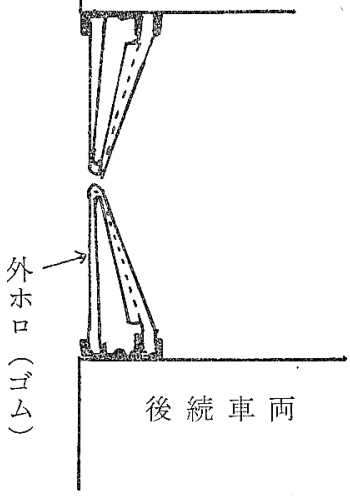

図17( 前部車雨と後続車雨との関係

にあるが，防音效果を劣げるため厚さ $30 \mathrm{~mm}$ の軟質ポ リウレタンフォームを直径 $3 \mathrm{~mm}$ のホロ管と一緒にし て，ナイロンターポリンで㣣み，クロロプレンコーティ ングしてある。外亦口徒来の東雨に見られなかったも

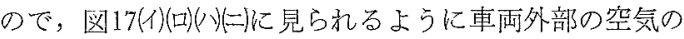
流れをよく香るために車両外側に密側雨側に取付け，材 料としてハイパロン塗装した NR-SBR を用いている。

\section{9 電 線}

電線関係はブチルゴム絶縁クロロプレンシース電線, ポリエチレン絶縁クロロプレン需線などが電源, 通信用 それぞれの用途として朋いられている。 


\subsection{0 その他}

䧃かい型物ゴムが主としてパッキング，あるいはクッ ション用, 緩衝用としてたくさん用いられているが，こ こでは割愛させていただく。

\section{3. あとがき}

以上のように多種多㥞のゴム製品が各分野に用いられ ているがここに紹介したのはその中で主として変った 使い方をした興味深いと思われるもの定選び出したので 西る。

ゴム製品の充分な利用がなされなければ現在のような 安全で快適な超特急は生れなかったであろうと思う。ま
して本闰の高速化に伴いゴムの特性をいかにフルに活用 するか，いいかえればゴムなくしては龺両の近代化に達 しえないとまでいっても過言ではないと思う。人類文化 の発展に件い，われわ机ゴム技術者のたゆ志好努力と研 究がよりよき社会を作って行く基礎となること文信じて 拙等をおきたいと思う。

最後に種々資料や写真を提供していただいた臨車設, 研究所の国枝技㸬, 公報係の平井職員の方々に㕌く感謝 の意を表します。

\section{引用文 献}

東海道新幹線 角本良平

\section{园ゴム用語}

JIS K 6200-1965

77 型加硫（かたかりゅう） mo(u)-ld cure, mo(u)-lding 末加硫ゴムを型に入れて加圧加硫する方法を いう。

78 カタサ

hdrdness

ゴムの表恶に押付けられた押針や球などの圧 入に対するゴムの相対的な抵抗を表わす数值 をいう（JIS K 6301を参照のこと）

79 カタサ試験機（かたさしけんき）

hasdness tester

ゴムのカタサを測定する試験機をいい，スプ リング式と定荷重式がある（JIS K 6301を参 照のこと）

80 型製品（加たせいひん）

mo(u)ld goods

ゴム，ゴムと金属，ゴムと繊維などで作られ た型加硫製品をいう.

81 型縮ミ（かたちぢみ） mo(u)lded shrinkage

型加硫した製品を型から取出し冷却したと き，収縮のため型の内容積より小さくなるこ とをいう。

82 型流レ（かたながれ） mo(u)ld flow

型加硫において未加硫ゴムが型内で活動する 現象をいう。

83 ガタパーチャ gutta-percha (G.P.)
赤鉄科 (Sapotaceae) の主としてパラキウム 属 (Palaquium) の植物の樹液から採取され たもので, 主成分はガ夕炭化水漜と呼ばれる トランス 1,4 ポリイソプレンからなる.

84 カットシート製品（かっとしーとせいひん） cut sheet goods

素練り，混合を行なったゴムをマスチケータ 一で韲練したのち円筒形の鋳鉄製つぼにプレ スで詰め, 円柱形に形成されたゴムの中心に 心金を大れ，これを軸にして回䎐させつつ回 転ナイフで淂い带状のシートを切断し，この シートを所定の形に成形し，冷加硫または熱 加硫によりつくられる製品をいう.

85 加熱空気老化試験 air-oven ag(e)ing test （かねつくうきろうかしけん） ゴム試験片を規定温度に保ったギャー式老化 試験機に入れ，加熱酸化させる促進老化試験 をいう（JIS K 6301）を参照のこと.

86 カバーゴム cover rubber ベルト，ホースなどの表面のゴム層をいう.

87 カビ mo(u)ld ゴム，特にラテックス中のショウ液物質がよ く洗い流されていないシートゴムの表面に生 ずる微生物の集落をいら。

88 ガラス軽移点（がらすてんいてル） glass transition point 二次転移点の項を参照のこと. 